\title{
POSTHUMANISM, THE TRANSCORPOREAL AND BIOMOLECULAR ARCHAEOLOGY
}

\author{
Christina Fredengren
}

This paper will discuss the tensions between the humanities and sciences within archaeology and examine how these tensions exist, both in how identity and personhood are understood, and in different views of epistemology and ontology. From a basis in critical posthumanism it is argued that unnecessary boundaries have been set up between the body and the environment. The concept of the transcorporeal allows for rethinking the connection between bodies and landscape, enabling us to discuss the environment inside. This approach can provide an alternative framing for the use of the sciences in archaeology, particularly for osteology and DNA and isotope analysis. Biomolecular mapping of body networks allows for a better understanding of the configuration of specific historic bodies as well as for discussing ethics. Furthermore, there may be a case for describing analysed bodies as figurations, rather than as identities.

Keywords: Posthumanism, anthropocentrism, osteology, DNA, isotope, human-animal relations, hauntology, environmental humanism

\section{INTRODUCTION AND THE PROBLEM}

The fields of science and humanities have experienced an increasing incompatibility over the past fifty years or so. A concern is that the linguis- 
tic turn and social constructivism have downplayed materiality and the sciences. There has been an increasing difference in theory and methods as well as a lack of acknowledgement of each other's results. At the same time there have been developments within nano-technology, biogenetics etc. that challenge the humanities and question what a human being is and may become. The quantum physicist Barad (2007, 20I2) argues that both fields have to change in order to develop. Latour has described this great divide as an obstacle, as many problems today need a research scope that looks upon phenomena as entangled cultural-natural networks (1993:5, 97-100). The challenge for the future needs to be met by cooperation between many fields of research.

The "divide" is also recognized in archaeology, and a major challenge is how the subject, where some have sided with social constructivist approaches and others are based in the sciences, can find alternative ways of being transformed by each other's knowledge. This paper focuses on osteology and the biomolecular techniques such as isotope analysis and DNA that have provided the archaeological community with new methods for understanding the past and have been used in particular to discuss identities. These techniques have become a part of the general toolbox for research as well as for contract work, and the field is maturing. The results of these analyses are used in popular science and are important for how many people understand and act in the world.

While osteology and isotope analysis are not deemed controversial, the use of DNA analysis is often more contested. Debates about DNA technique and the challenges of having different epistemological approaches took place in the last decade (Renfrew 2000; Shennan 2002; Welinder 2003; Kristiansen 2004). However, these techniques have also been questioned more recently due to presumed racial analogies and essentialist claims (Cassel 20II). It is clear that some of these tensions are derived from how identity and personhood are approached in archaeology, and in order to move on from this position there is a need to question the relationship between constructivism and biological determinism and to deal with the nature:culture divide. Both the extreme positions of biological determinism (where social identities are determined by presumed natural biological traits such as sex, race and disability) and cultural essentialism (where a background in a particular culture determines identity, and gender roles, for example, are seen as prescribed within a given culture) are problematic (see Lykke 20I0:2324, 203-204). The use of DNA is also critiqued at an overall level and it is perceived that "archaeogenetics lacks a consistent theoretical framework" (Oliveira 2008:III). However, there may be more at stake than just different views of how to gain knowledge; there are also alternative 
understandings of how the world exists, which in turn has bearings on ethical issues.

\section{POSTHUMANISM, FEMINISM AND BIOMOLECULAR ARCHAEOLOGY}

At the risk of oversimplifying, critical posthumanism (see Braidotti 2013:I, 26-29, 45-54, I92-I94) can be described as the questioning of anthropocentrism and the ontological divide between humans and nonhuman others with a focus on the interrelation between different species and the surroundings, arguing for a nature:culture continuum. By mapping a variety of embodied subject positions it raises issues about power, ethics and accountability from a standpoint where subjects have multiple belongings. The feminist element lies in the view that the universal "human" in humanism seldom includes all humans and that rights and resources keep being distributed through racial, gendered, species and class agendas. This approach does not stop at a critical deconstruction, but also continues to work affirmatively for more sustainable futures. There are variants of posthumanism. For Bogost (201 2:5-10) not all posthumanism is posthuman enough. Bogost's object-oriented ontology (OOO) is based on Meillassoux's critique of correlationalism, i.e. the legacy of Kant in postmodern thinking, which means that what exists is only what is possible to capture in human thought (Meillassoux 2008:36, see also Normark 20I 2 and critique of Bogost in Alaimo 2013:15, I8).

As Hjørungdal (2OI2) argues, with reference to the posthumanism of Barad, it is important to probe into the relationship between science, nature and culture in archaeology. This would allow for an alignment with the symmetrical and new materialist approaches in archaeology (Webmoor 2007; Webmoor \& Witmore 2008; Normark 20I 2; Sørensen 2013) as well as for furthering the studies of relationships between humans and animals (Armstrong Oma 20IO) and the environment. It is essential to state that critical posthumanism focuses on how important the interaction with other non-human actors is and is not about devaluing humans.

This paper aims to examine how critical posthumanism can be useful for navigating between the sciences and humanities when discussing bodies, subjectivities and ethics. A major question is "who" is materialized through the use of science in archaeology? How can this process be understood and how can a researcher take responsibility for the use of the outcome in a way that works affirmatively?

Two concepts will be central in this examination: the transcorporeal and figurations. Alaimo (2010), drawing on Barad (2007), has pro- 
vided the concept of the transcorporeal as a way out of the dilemma of essentialism versus constructivism. The concept can be used as a way of "Imagining human corporeality as transcorporeality, in which the human is always intermeshed with the more-than-human world" and this captures how "the substance of the human is ultimately inseparable from 'the environment" (Alaimo 20I0:2). In this way a person, human and non-human, is a network of more or less persistent nature:culture relationships. Figurations can be described as conceptual personae that map subjectivities as they emerge in relation to others and to power locations (see Braidotti 20I3:I63-I65). It will be argued that a focus on transcorporeality and mappings of "figurations", instead of a focus on identities or personhoods, would enable the discussion to take a step forward and would provide guidance from a path of troubles and hence drive a feminist agenda in archaeology.

\section{FROM IDENTITY AND PERSONHOOD TO NETWORKS AND RELATIONS}

The issues of identity and personhood have been dealt with in a number of publications and focus mainly on humans. Identity can for example be discussed as self-view or what distinguishes groups of "us" from groups of "them" (see Jones 1997; Insoll 2006). Increasingly the term personhood has been used in archaeology, indicating an interest in how existence is dependent on relations with others as well as that the establishment of a person is a question of acknowledgement and how someone is conceptualized in various communities (Fowler 20I0). Personhood can be shaped by dress or gear, but also through other interactions where gender, age and tasks matter. Hence, material objects added to the body contribute to the construction of a social persona. There has been a growing interest in the body in archaeology with regard to understanding how bodies have moved through space in phenomenological studies and with regard to how the body has been socialized (see Sørensen 1995; Meskell \& Joyce 2003; Gilchrist 2009; Dommasnes et al. 2010) as well as how diverse ways of understanding the body have gone from being appreciated not as epistemologies, but as coexisting modal ontologies sustained by different materialities (see Harris \& Robb 20I2). One example is that artefacts, such as wedding rings or prostheses that have been added to the body, can become so entangled with a person that they deserve to become a part of a burial (Sørensen 2013:8). It has been suggested by Damm (20I2:I26, I3 I-I32) based on examples from Northern Fennoscandia, that people would have had a multitude of sit- 
uated and overlapping identities. Some of these may have been tied to gender or group affiliation or were related to communities of practice, and these involved relations between humans and non-human agents such as tools or raw materials. Damm has used this thinking to look at networks visualized in distribution maps of artefacts such as northern sets of fishhooks suggesting, that they represented such shared practices and identities (20I2:I26, I3I-I32).

Materially merged personhoods are not only for humans. There is archaeological evidence for trans-species cross-dressing, of humans becoming animals and animals transformed into fantasy creatures. Animal headpieces, leads and harnesses were important in the transition between the Late Bronze Age and Iron Age in north-west Europe, as well as horned headpieces for humans and animals (see Fredengren 2002:195-198). On the one hand the dressing up of animals preserves the human as the main actor. On the other hand these harnesses work as interconnectors and translators between human and animal emotions, body language etc., but dogs or horses can on occasions also establish relationships with their particular gear, for example a favourite collar or a preferred saddle (see Argent 20Io), and these objects change the capacities of the human-animal relationship. However, the entanglement between materials and the body is often exemplified by addons and extensions of the body, and for that reason leave the body as an essential entity.

\section{GENDERED DOWN TO THE BONES?}

Sofaer (2006) has pointed out the gap between science-based osteology and the social constructivist approaches of archaeological writings. It can be argued that the materiality of the body and social practices coincide in the skeleton as it bears marks of the history of the body. As stated by Butler, biological sex is also socially constructed, down to the bone so to speak, and the social construction comes into being by a continuous performance of social norms. Hence gender is constantly in the making and acted out in the body (Butler I999 (I990): 9-I I, 45-49, see for example Joyce 2000 for use in archaeology). In effect biological sex determinations of osteology and DNA would, under Butler's influence, be considered as variants of socially constructed gender. Rather than discussing sex as a biological category it is often argued that gender is a socially constructed category built through historically determined power structures, where for example material culture, sites and landscape were used in the formation of the cultural categories of man and 
woman, or any other of a large variety of gender categories (see Nordbladh \& Yates I990). These cultural categories would be different from the biologically determined categories that would be gathered under the label of sex determination.

From the I990s when Butler argued that sex was also a social construction, the corporeal re-emerged in feminist studies (Braidotti I994; Grosz 2004). The focus was to theorize the materiality of the sexed body with an avoidance of biological determinism (Lykke 2010:204). Contrary to Butler's deconstruction of sex, Braidotti (I994:I00) has emphasized the need to repossess the historicity of various female bodies and to "assert the specificity of the lived, female, embodied experience". Furthermore, to maintain the gender category without acknowledging biological sex may in fact sustain hierarchies that feminism was meant to change. By ignoring "sexual difference" such a perspective fails to deal with how patriarchal norms are projected on to most bodies (Lykke 20IO:I2I). As Haraway (I99I:I97, cf. Barad 2007:I50-I5I) says, social constructionism leaves the sexed body as a "blank page for social inscriptions". In archaeology (Fahlander 20I 2:I42-I43) has furthered such a corporeal approach where the materiality of the body and sexual differences may be understood as facilitating certain actions and restraining others, where for example height improves capacity to reach and the body can be understood as a Latourian actant.

Contrary to the social constructivist argument, there is a need to "get real" and take the materialization of bodies seriously and acknowledge both stability and variance without ending up in an essentialist position with fixed identity categories. Barad, following Niels Bohr, has argued that not even atoms have distinct ontological identities. All bodies (human and non-human) come into being through material-discursive entanglements (Barad 2OI 2:32), that is, through mergers of both concepts and materiality. In what is termed agential realism Barad (2007:225, 2OI 2:30-33) focuses on the mutually transformative interplay, intraaction, between numbers of different actors that result in new phenomena coming into existence. These transformations perform agential cuts that precede socially constructed identities. This is a science-based relational ontology that leaves essentialism behind. Instead there are ongoing materialization-conceptualization processes that bring phenomena into being. Barad calls this an onto-epistemology to describe how what exists in the world and knowledge about the world cannot be separated. In effect a body is a temporal assemblage that emerges and materializes through various entangled processes.

For example, Fausto-Sterling's work shows how gendered activities shape the bones of the body and that tissue changes and recursively 
acts and facilitates alternative actions (2005). Human bones are objects that change both during a person's life and after death, but there is also a whole range of historical intra-actions that differentiate bodies over time. It is worth noting that the sexing of some skeletons from the Mesolithic, such as that from Store Mosse in Scania, has given contradictory results. The postcranial body was judged as female by observing birthmarks on the pelvis, but the craniums had developed coarser male characteristics following evolutionary processes and/or activities such as chewing sinew or meat (Nilsson et al. 1979:234). Furthermore, the form and structure of the skulls of elderly females tended to accumulate male features (Meindl et al. 1985). At the other end of history, in the medieval period, it is clear that male skeletons from certain regions are more gracile (Kjellström 2005). In effect the physical skeletal realities of being female or male in the Mesolithic would differ from the physical skeletal realities in later periods. Furthermore, the skeleton would change during the life course with regard to male or female characteristics. Biological sex can become different due to various intra-active changes. It is therefore clear that both the male and the female morphology can change over time.

\section{TRANSCORPOREALITY AND ISOTOPE ANALYSIS}

Alaimo $(2010: 2,22)$ has described the human body as transcorporeal, where the boundary between the body and its surroundings are blurred; "biology and politics merge as people, places and substances merge." This is a beneficial concept that places the results of archaeology such as isotope analysis in a theoretical frame and shows the entanglement between the skeleton, the visceral parts of the body and the environment. Human and animal diet can be investigated by measuring carbon and nitrogen values in the skeleton. These values tell whether the individuals had a marine or a terrestrial diet and whether their food came from low in the food chain, as in a vegetarian diet, or if it consisted of meat higher up on the scale (see Eriksson 20I3). Often the results are popularized under the saying "you are what you eat" (see Schulting \& Richards 2002:153), which is compatible with the concept of transcorporeality. Furthermore, both strontium from bedrock and oxygen from water change tissue and bone and can be used to see the interchange between the body and the environment at various stages of the life course, and are used for discussing mobility and migration.

As Alaimo (2010:4) argues, "the environment' is not located somewhere out there, but is always the very substance of ourselves." Hence, 
biomolecular archaeology maps how food, bedrock and water would have materialized and transformed the body. Rather than seeing the body as a stable entity it is understood as being porous, with a constant interchange with the entity's surroundings. It is important to state that these analyses also track various relationships with other human and non-human beings and thereby is an example of how nature and culture are entangled. Interesting research has been carried out on the issue of breastfeeding in the past, where the isotopes show that babies fed on someone high up in the food chain, i.e. the milk from another human being, possibly their mother (see Fornander 20I I; Howards 20I3). These results can be taken a step further as evidence not only for the presence or absence of breastfeeding, but also to give evidence about the formation of relationships between a female and a child, or in the case of animal milk replacement, as evidence for a human-non-human relationship.

These analyses could suggest a link to particular types of food, various animals or places in the landscape and would be a way of moving beyond the surface of the body. But it is important to take a step further in the analysis and ask who came to access what food, who dwelled permanently in the landscape, and who had to move? Such mapping is a method to examine geo- and bio-political relationships, where food and the landscape are re-enacted in the body to become a part of the personhood in material ways. These biomolecular analyses can easily facilitate a discussion of the network that runs through the body. To discuss the body as a transcorporeal assemblage (an assemblage here means an effect-producing gathering (see Deleuze \& Guattari i998:3-4)) would be a way to focus on the body as a permeable space where various actors co-work in forming the person, which also has recursive effects beyond the person. However, as materializing phenomena, these assemblages are more than the human/non-human networks described by Latour. This is by no means contradictory to the extra somatic (add-on) personhood that has been discussed above, but rather an expansion that takes into account exchanges with other species as well as the environment.

\section{DNA, MULTIPLICITIES AND BECOMING}

Understanding the body as a transcorporeal assemblage may affect how archaeologists use and contextualize DNA analysis in archaeology. Genetic analysis of mitochondrial DNA has been used to trace a direct maternal line and the use of Y-chromosomes to show male lineage. The results are often communicated by a family tree of genetic lineage (Åsberg 2005). The family tree with a common ancestor was an idea mo- 
bilized politically in both imperialism and colonialism during the igth century (Åsberg 2005:245, 252-253; McClintock 1995; Cassel 20II). As has been pointed out by M'charek (2000), population genetics uses one particular part of the DNA sequence and not the full amount of genes present in the biological being to form lineage tree maps. It shows the history of particular genes. If the scientific results are used in a thought structure of genealogy, these results will describe a history and connections that have a source and origin and causality and that give rise to narratives of linear progress, for example, for a family, tribe or clan, and exclude other ways of perceiving ancestry and family. While such relations may have been important, it downplays networks of care and respect built on other grounds or such that include relationships to other species and things.

One could develop this discussion of sorting DNA in a tree structure by making use of the contrast between arborescent and rhizomatic thinking, whereas "unlike trees or their roots, the rhizome connects any point to any other point..." (see Deleuze \& Guattari I988:5-7, 2I). Whereas the use of DNA to trace genealogy could be understood as a form of arborescent, linear and hierarchical thinking, rhizomatic research maps other possibilities and searches for messier connections. The latter approach would investigate relations in a horizontal way, asking questions about what networks made this person come into being and thrive. This may imply conceptualizing the beings we study as intra-acting assemblages in both the exterior and the interior. There is a transcorporeal aspect of genetics that needs to be discussed as the body consists of DNA from more than one species. Haraway (2008:3-4, $3 \mathrm{I}^{-}$ 32) describes the human body as consisting to $90 \%$ of other genomes than the human, such as those of microorganisms, bacteria and fungi, important for our existence. In writing "To be one is always to become with many" (2008:4) Haraway links to Deleuze and Guattari who argued that "Since each of us was several, there was already quite a crowd" (1988:3). In the human body, for example in the intestines, there are also traces of other animals, parasites and diseases, some of which may work in a beneficial way for the body and others with malevolent effects on health and life. Recent analysis of DNA in dental plaque (Adler et al. 2OI3) provides evidence of such intra-actions and the co-working with bacteria related to shifts in diet. The analysis of DNA has been used to track the development of, for example, leprosy in medieval and modern populations (Schuenemann et al. 20I3). In these cases the bacteria has become such an integral part of the body that it still remains in the skeleton's DNA and thereby is an example of how there is a life-changing entanglement between the human and bacteria within the body. Besides 
this DNA from animals, plants and humans can be found distributed in faeces, soils and sediments (Hebsgaard et al. 2009). This so-called dirt DNA attests to how bodies become distributed in the landscape, i.e. as transcorporeal assemblages outside the body, in the environment, and could be used to understand the bio-politics of who was where and at what times.

DNA can be used for sexing skeletal material. Åsberg (2005) has pointed out that the tree genealogy omits looking at chromosomal variances, such as the presence of sex/gender mixes of XXY, and XYY to search for sexual ambiguity and chromosomal intersex features. Such chromosomal variants may however show up as deviations in the DNA measurement of sex through the mathematical models (see Skoglund $e t$ al. 2013). However, such studies may be complicated to carry out on fragmented ancient DNA. Furthermore, it can be debated whether DNA really provides a final judgement on sex as compared to osteological determinations or other relations and activities important for making up personhood. There are many actors that co-work to form female and male subjectivities. The find of a Y chromosome is an indication which shows a body had the possibility of becoming a man. However, bodies are full of potentials that may or may not be realized in various historical settings. There is not always a correspondence between genotype and phenotype; i.e. the hereditary aspects may be expressed differently depending on circumstances. However, this does not mean that the DNA analysis should be disregarded; on the contrary, science is important as it contributes together with other mappings to an understanding of rather complex subjects.

Besides discussing a variety of biological sex, DNA is used in archaeology to look at appearance and to establish hair, eye and skin colour (see Draus-Barini et al. 2013). The statistical models used in DNA counts can also be set at looking at factors such as genetic diseases and disability. Here too the question of constructivism contra materialism, as well as that of ethics is at play. M'charek (2010:3 I6-319) has studied the use of facial reconstruction, osteology and DNA of a human body found in Eindhoven in the Netherlands and its role for Dutch identity. It was shown that the person who emerged from the analysis was dependent on other relationships such as a tension between western and Muslim history and the wish to find a healthy body with white skin. However, this does not mean that appearance analyses should be avoided as skin or eye colour may have been socially charged in the past as well. Likewise there is a tension between the social constructivist arguments that claim that disability is caused by a society that acts adversely to a body that does not fit the norm and an analysis built around the physi- 
cal realities of a disabled body. In the first case disability would lessen by removing prejudice. However, such a position runs the risk of making invisible the action capacities of a disabled body (Siebers 200I:738). To use DNA for investigation of appearance or handicap may be a way of understanding mechanisms of racism and discrimination in the past and at the same time acknowledge the physical realities of the body, but DNA on its own reveals a partial picture and does not straight away translate into identity.

\section{APPARATUSES, HAUNTOLOGY AND ETHICS}

There are other important implications for archaeology of using critical posthumanism. Just as the various theories of the humanities are apparatuses that bring about results, the scientific outcomes are also dependent on apparatuses as machines, computer programs and concepts. Barad (2007:I46) has described them as open-ended "boundary making practices" that carry out cuts in an interconnected world in order to observe it. They produce distinctive material-discursive beings that, at the same time as they come into being, exclude other phenomena or concepts. In effect every such concept is "haunted" by its exclusions (Barad 20I0:253). In the case of DNA analysis, it is both a question of what sequence of the genetic mass is selected for analysis, and also what parameters the computer counts are set to carry out and what programs are available which would perform such complementary exclusion. Hence it is important to be observant about who or what are the excluded others.

However, this does not mean that science is a social construct. Instead Barad (I998:II2) argues that while scientific knowledge production is dependent on "social factors", the universe "kicks back". This means that the process of mattering can come to us as a surprise or as above in a haunting. However, it is not a question of ghostly epistemologies and various perceptions of the world; it's about ontologies. It is "as if measurements conjure things into existence" (Barad 20I0:257). The discussion of hauntology in Barad (2010) refers back to Derrida's (1994) argument of how Marx's theories will continue to haunt society as a ghost. Marx's critique installed awareness of social injustice and responsibility. This is important, Barad argues (2010:260-26I), as hauntology points out disjunctures in time. Possibly not only thoughts and meanings from the past interfere with the present, but also materialization processes in form of bodies, buildings or landscapes continue to entangle and haunt the present and the future. The past, as a hauntology, is effective as it 
is both present and absent in an ongoing space-time mattering. Barad (20I0:260-26I), however, grounds hauntology in science.

Furthermore, a classical ethical problem that was facing Bohr and Heisenberg (Barad 2010:242) is also relevant for archaeology: does a scientist have the moral right to work on methods that bring about research that can be misused in other contexts? It could be argued that such research is as dangerous as the relativism of some of the extreme postmodern theories, which may leave history open for anyone to compose. Barad's approach is trying to deal with history and the past as an ongoing process, but this is not a relativism where any history writing can pass by. What Barad suggests is an ethics of entanglement with an onto-epistemological grounding, "understanding which differences matter, how they matter, and for whom" (Barad 2007:90). This means that actions and choices need to be taken with a reflection on the effects for the excluded others, which means accountability and responsibility for the partial webs the researcher co-produces. In effect the use of archaeological methods, scientific or humanistic, will imply a reasonable awareness of the potential uses of the results, for example in racial and sexually discriminating agendas, and such awareness is reflected in the presentation of the research. According to Barad, ethics is part of the materialization processes. However, such ethics is also "about making connections and commitments" (Barad 20I0:266) and mapping ongoing materialization processes.

\section{FIGURATIONS AND FRAMES OF RECOGNITION}

A way out of the dilemma where the identities presented by the use of scientific results suffer essentialist and racist critique could be learned from Braidotti's (1994, 2002, 2013) use of the term "figuration". A figuration is "a politically informed account of an alternative subjectivity" (I994:I), which works as a feminism by offering affirmative ways out of hegemonic power formations. However, figurations are more than concepts, they are lived realities that consist of body, emotion and mind. "These are highly specific geo-political and historical locations - history tattooed on your body" (Braidotti 2002:3). Haraway (2008:4) describes these as knots where bodies and meanings co-shape each other. Working with figurations aims to map power relations but also has an inbuilt hope of resistance to suppression (Braidotti 20I I; Lykke 20IO:38).

Butler has traced such power relations in her later works, such as the book Frames of War: When is Life Grievable? Butler (20I0:3) still argues that the body is exposed to "social crafting and form" due to 
social and political forces and that neither biological sex can be taken as granted as a principle for social organization nor is there an essence to what a human body consists of. However, Butler at the same time acknowledges transcorporeal effects, where bodies are meeting places where issues about how a person is regarded, supported or which social networks the person is involved in are re-enacted. It is this "framing" that either enables or disables what is socially regarded as a life worth caring for. The frames determine which lives are "produced according to norms that qualify it as a life" and which are recognized as precarious, vulnerable and therefore also in need of protection from violence and abuse (2010:3, 52-53). These writings add a dimension as they lift the issue of personhood beyond questions of dress, gear or tasks. The participation in sustainable networks with others that may provide food, care, shelter, social relationships, and protection from violence is also extremely important. Another issue is whether these frames of recognition extend to or exclude non-human others such as animals.

The results of osteology and biomolecular analysis can be used to see which lives were considered as worth caring for. In order to carry out such analysis there is a need to observe whether they were exposed to violence during their lives or if they were well nurtured, or what type of food networks people would have been integrated in. Nutritional inadequacies or illness may show in the teeth that develop during childhood, recognized as hypoplasia (Hillson I986:I30). Iron deficiency due to lack of iron uptake caused by parasites, diet or blood loss can be noted as porotic hyperostosis or cribra orbitalia (Buckley 20II:536). Hence there are some bodies that may not have been a part of fully providing food networks during their life. Malnutrition may be a result of some bodies not having been classified as worthy of caring for and hence not linked into a stable food network. The presence of parasites may suggest that their food network was also linked to these non-human agents.

To take the scientific results seriously and to acknowledge them would unfold myriads of material connections and companion species that coexist between and within bodies. To articulate this evidence would be a basis for a resistance to the reductionism of racism, speciesism and sexism. In dealing with the question of who was killed, sacrificed or cherished and treated differently, such historical, environmental bio- and geo-political locations can be mapped as they form a part of transcorporeal assemblages. Using the scientific result for more complex mappings of the body's processes is a way of bringing in a posthumanism that acknowledges physical realities. In turn these results can be used to declare that living beings are more than what is covered by an identity label. The results can be used to reveal injustices such as racism, 
sexism and speciesism in the past. As suggested in this paper, one way to capture both the scientific endeavour and the ethical reflection is to acknowledge that archaeological analyses do not reveal identities, but rather complex, entangled and fleshed out figurations. In an attempt to answer the main question of this article, that is "who" is materialized through the use of science in archaeology, the answer is that it is various figurations, some of which have more hopeful pasts and futures than others. What deserve further discussion is the proposed alternative bases for critical posthumanist ethics (see Braidotti 2013:93-94, Iо०) in which co-dependence is more important than recognition and where sustainability is in focus.

\section{DISCUSSION AND CONCLUSION}

Critical posthumanism as represented by Alaimo (2010), Barad (2007, 20I2), Haraway (2008), Braidotti (1994, 2002, 20II, 2013) and Butler (20I0) can alter the arguments about identity, personhood and subjectivity and thereby make room for an increased interchange between science and the humanities in archaeology. What is important in these theories is that they question the anthropocentric focus in humanism, where the study of the human construction of meaning has been in focus, and open up for a study of how relations between humans and non-humans are figurated. This places an increased focus on mapping how entangled nature:culture webs coincide or dissolve in bodies and how non-human actors are important for the development of various events. Such a posthumanist focus on archaeology in general and biomolecular approaches in particular would also take an interest in the techno-science aspects of work in the laboratories. At the same time this perspective recognizes scientific results and aims to question the division between nature and culture or the inside and outside of bodies. It also allows for placing observed gender differences within a dynamic way of thinking. One possibility worth pursuing is to change the debate on identities or personhoods by adding that these are indeed figurations which are nature:culture networks that coincide around and within bodies; while such figurations have ontological bearings they undergo change over time. A research task may then be to map such figurations at different points in time as a basis for a historical analysis. As discussed in the paper, to place isotope results within a transcorporeal framework would allow envisaging personhood differently from the social constructivist approaches. It rather articulates how bodies have a perforated surface where materials merger with the body, which both changes and intra-acts on the world. 
From a posthumanist feminist viewpoint it would be important to take into account the scientific results, as they would be ontologically significant evidence of such physical relations. It would emphasize a social and ethical responsibility for scientific production in that the suggested figurations also incorporate reflections on their future effects. Such a position also obliges the researcher to carry out a biomolecular archaeology that would be ethically reflective on whatever persons are brought into being through the humanistic/scientific practice. This reflexivity needs to be combined with an awareness of how taxonomies and visualizations may be used in both past and future political agendas. Such archaeology would pursue an environmental humanism and investigations into bioculture and continue to ask questions about the interrelatedness of biology, culture and politics. It would be particularly interesting to analyse those life-changing histories where figurations change distinctly from the intra-actions with the environment and to analyse how frames of recognition alter over time. This may be a further development of osteology, isotope analysis, chemical analyses or epigenetics. This perspective calls for a responsibility towards the hauntological effects of the material past and in effect lets these excluded others come home and also act as spectres in the future.

Christina Fredengren
Department of Archaeology and Classical Studies
Stockholm University
SE-I06 9I Stockholm
Sweden

\section{REFERENCES}

Adler, C. J., Dobney, K., Weyrich, L. S., Kaidoinis, J., Walker, A. W., Haak, W., Bradshaw, C. J. A., Townsend, G., Soltysiak, A., Alt, K. W., Parkhill, J. \& Cooper, A. 20I3. Sequencing ancient calcified dental plaque shows changes in oral microbiota with dietary shifts of the Neolithic and Industrial revolutions. Nature Genetics 45 . Pp. 450-455.

Alaimo, S. 20I0. Bodily Natures: Science, Environment, and the Material Self. Indiana: Indiana University Press.

Alaimo, S. 20I3. Thinking as the Stuff of the World. O-Zone: A Journal of ObjectOriented Studies. Issue I: Object/Ecology. Pp. I3-2I.

Argent, G. 20I0. Do the clothes make the horse? Relationality, roles and statuses in Iron Age Inner Asia. World Archaeology. Vol. 42. Pp. I5 I-I74.

Armstrong Oma, K. 20Io. Between trust and domination. World Archaeology. Vol. 42. Pp. $\mathrm{I} 75-\mathrm{I} 87$. 
Barad, K. 1998. Getting real: Technoscientific practices and the materialisation of reality. Differences: A Journal of Feminist Cultural Studies Io(2). Pp. 87-I28.

Barad, K. 2007. Meeting the universe halfways. Durham: Duke University Press.

Barad, K. 20IO. Quantum Entanglements and Hauntological Relations of Inheritance: Dis/continuities, Space Time Enfoldings, and Justice-to-Come. Derrida Today 3:2. Pp. 240-268.

Barad, K. 20I 2. Nature's Queer Performativity. Kvinder, Køn \& Forskning. Vol. I-2. Pp. 25-53.

Bogost, I. 20I 2. Alien Phenomenology, or What It's Like to Be a Thing. Minneapolis: University of Minnesota Press.

Braidotti, R. I994. Nomadic Subjects: Embodiment and Sexual Difference in Contemporary Feminist Theory. New York: Columbia University Press.

Braidotti, R. 2002. Metamorphoses: Towards a Materialist Theory of Becoming. Cambridge: Polity Press.

Braidotti, R. 20I r. Nomadic Theory: The Portable Rosi Braidotti. New York \& Chichester: Columbia University Press.

Braidotti, R. 2013. The Posthuman. Cambridge: Polity Press.

Buckley, L. 20I r. General survey of the osteoarchaeology. In: Cahill, M. \& Sikora, M. (Eds). Breaking ground, finding graves - reports on the excavations of burials by the National Museum of Ireland, 1927-2006. National Museum of Ireland. Monograph Series 4, vol. 2. Pp. 527-578. Bray: Wordwell.

Butler, J. 1999 (1990). Gender Trouble: Feminism and the Subversion of Identity. New York: Routledge.

Butler, J. 20I0. Frames of War: When is Life Grievable? London: Verso.

Cassel, K. 20 I r. I genernas spår. Globala nätverk eller lokala isolat? In: Andrén, A. (Ed.). Förmodern Globalitet: Essäer om rörelse, möten och fjärran ting under Io ooo år. Lund: Nordic Academic Press. Pp. 229-244.

Damm, C. 20I 2. Interactions Within and Between Collectives: Networking in Northern Fennoscandia. In: Damm, C. \& Saarikivi, J. (Eds). Networks, Interaction and Emerging Identities in Fennoscandia and Beyond. Proceedings from the International and multidisciplinary conference in Tromsø I3-16 Oct. 2009. Mémoires de la Société Finno-Ougrienne 265. Helsinki: University of Helsinki. Pp. I25-138.

Deleuze, G. \& Guattari, F. I988. A Thousand Plateaus: Capitalism and Schizophrenia. London: the Athlone Press.

Derrida, J. 1994. Specters of Marx: The State of the Debt, the Work of Mourning, \& the New International. New York: Routledge.

Dommasnes, L. H., Hjørungdal, T., Montón-Subías, S., Sánchez Romero, M. \& Wicker N. L. (Eds). 2010. Situating Gender in European Archaeologies. Budapest: Archaeolingua.

Draus-Barini, J., Walsh, S., Pospiech, E., Kupiec, T., Glab, H., Branicki, W. \& Kayser, M. 20I3. Bona fide colour: DNA prediction of human eye and hair colour from ancient and contemporary skeletal remains. Investigative Genetics 20I3, 4:3.

Eriksson, G. 20I3. Stable Isotope Analysis of Humans. In: Tarlow, S. \& Nilsson Stutz, L. (Eds). The Oxford Handbook of the Archaeology of Death and Burial. Oxford: Oxford University Press. Pp. I23-146. 
Fahlander, F. 20I2. Facing Gender. Corporeality, Materiality, Intersectionality and Resurrection. In: Back Danielsson, I.-M. \& Thedén, S. (Eds). To Tender Gender. The Pasts and Futures of Gender Research in Archaeology. Stockholm Studies in Archaeology 58. Stockholm. Pp. I37-I52.

Fausto-Sterling, A. 2005. The Bare Bones of Sex: Part I - Sex and Gender. Signs: Journal of Women in Culture and Society. Vol. 30. No. 2. Pp. I49I-I527.

Fornander, E. 20I I. Consuming and Communicating Identities: Dietary Diversity and Interaction in Middle Neolithic Sweden. Stockholm: Department of Archaeology and Classical Studies, Stockholm University.

Fowler, C. 20Iо. From Identity and Material Culture to Personhood and Materiality. In: Beaudry, M. \& Hicks, D. (Eds). The Oxford Handbook of Material Culture Studies. Oxford: Oxford University Press. Pp. 352-385.

Fredengren, C. 2002. Crannogs: A Study of People's Interaction with Lakes. Bray: Wordwell.

Gilchrist, R. 2009. Rethinking later medieval masculinity: The male body in death. In: Sayer, D. \& Williams, H. (Eds). Mortuary Practices and Social Identities in the Middle Ages: Essays in Burial Archaeology in Honour of Heinrich Härke. Exeter: University of Exeter Press. Pp. 236-252.

Grosz, E. 2004. The Nick of Time: Politics, Evolution, and the Untimely. Durham: Duke University Press.

Haraway, D. I99I. Situated Knowledges: The Science Question in Feminism and the Privilege of Partial Perspective. In: Haraway, D. (Ed.). Simians, Cyborgs and Women: The Reinvention of Nature. London: Free Association Books. Pp. I83-20I.

Haraway, D. 2008. When Species Meet. Minnesota: University of Minnesota Press.

Harris, O. J. T. \& Robb. J. 20I 2. Multiple Ontologies and the Problem of the Body in History. American Anthropologist I I 4(4). Pp. 668-679.

Hebsgaard, M. B., Gilbert, T. P., Arneborg, J., Heyn, P., Allentoft, M. E., Bunce, M., Munch, K., Schweger, C. \& Willerslev, E. 2009. The Farm Beneath the Sand - an archaeological case study on ancient 'dirt' DNA. Antiquity 83 (320). Pp. 430-444.

Hillson, S. 1986. Teeth. Cambridge: Cambridge University Press.

Hjørungdal, T. 20I 2. "Møder i Mosen" - Metodmöten i Maglemoses forskningshistoria. In: Nicklasson, P. \& Peterson, R. (Eds). Att återupptäcka det glömda: Aktuell forskning om forntidens förflutna $i$ Norden. Acta Archaeologica Lundensia. Series Prima in 4 . No. 32. Pp. 325-336.

Howards, R. 20I3. Weaned Upon A Time: Studies of the Infant Diet in Prehistory. Theses and Papers in Scientific Archaeology. Vol. I4. Stockholm: Department of Archaeology and Classical Studies, Stockholm University.

Insoll, T. 2006. Reader in the Archaeology of Identities. London: Routledge.

Jones, S. 1997. The Archaeology of Ethnicity: Constructing Identities in the Past and in the Present. London \& New York: Routledge.

Joyce, R. M. 2000. Gender and Power in Prehispanic Mesoamerica. Austin: University of Texas Press.

Kjellström, A. 2005. The Urban Farmer: Osteoarchaeological Analysis of Skeletons From Medieval Sigtuna Interpreted in a Socioeconomic Perspective. Stockholm: Department of Archaeology and Classical Studies, Stockholm University.

Kristiansen, K. 2004. Genes versus agents: A discussion on the widening theoretical gap in archaeology. Archaeological Dialogues II (2). Pp. 77-99. 
Latour, B. 1993. We have never been modern. London \& New York: Harvester Wheatsheaf.

Lykke, N. 20Io. Feminist Studies: A Guide to Intersectional Theory, Methodology and Writing. New York: Routledge.

McClintock, A. 1995. Imperial Leather: Race, Gender and Sexuality in the Colonial Contest. London: Routledge.

M'charek, A. A. 2000. Technologies of Population: Forensic DNA testing practices and the making of differences and similarities. Configurations 8. Pp. I2I-I59.

M'charek, A. 20I0. Fragile differences, relational effects; stories about the materiality of race and sex. European Journal of Women's Studies I7(4). Pp. 307-322.

Meillassoux, Q. 2008. After Finitude: An Essay on the Necessity of Contingency. Trans. Ray Brassier. New York: Continuum.

Meindl, R. S., Lovejoy, C. O., Mensforth, R. P. \& Don Carlos, L. 1985. Accuracy and Determination of Error in the Sexing of the Skeleton: Implications for Paleodemography. American Journal of Physical Anthropology 68. Pp. 79-85.

Meskell, L. \& Joyce, R. (Eds). 2003. Embodied Lives: Figuring Ancient Maya and Egyptian Experience. New York: Routledge.

Nilsson, T., Sjövold, T. \& Welinder, S. 1979. The Mesolithic Skeleton from Store Mosse, Scania. Acta Archaeologica. Vol. 49. Pp. 220-238.

Nordbladh, J. \& Yates, T. 1990. This Perfect Body, This Virgin Text: Between Sex and Gender in Archaeology. In: Yates, T. \& Bapty, I. (Eds). Archaeology after structuralism. London: Routledge. Pp. 222-239.

Normark, J. 20I2. The road of life. Bodies-politic in the Maya area. In: Back Danielsson, I.-M., \& Thedén, S. (Eds). To Tender Gender: The Pasts and Futures of Gender Research in Archaeology. Stockholm Studies in Archaeology 58. Stockholm: Stockholm University. Pp. I $17-136$.

Oliveira, H. 2008. Molecular Biology and the Human Past. A Theory of Archaeogenetics. Archaeological Review from Cambridge 23. I. Pp. 109-I 26.

Renfrew, C. (Ed.). 2000. Archaeogenetics: DNA and the Population Prehistory of Europe. Cambridge: McDonald Institute for Archaeological Research.

Schuenemann, V. J., Singh, P., Mendum, T. A., Krause-Kyora, B., Jäger, G., Bos, K. I., Herbig, A., Economou, C., Bengak, A., Busso, P., Nebel, A., Boldsen, J. L., Kjellström, A., Wu, H., Stewart, G. R., Taylor, G. M., Bauer, P., Lee, O. Y. C., Wu, H. H. T., Minnikin, D. E., Besra, G. S., Tucker, K., Roffey, S., Sow, S. O., Cole. S. T., Nieselt, K. \& Krause, J. 20I3. Genome-wide comparison of medieval and modern mycobacterium leprae. Science I 2 July 20I3. Vol. 34I. No. 6I 42. Pp. I79-I 83.

Schulting, R. J. \& Richards, M. P. 2002. The wet, the wild and the domesticated: The Mesolithic-Neolithic transition on the west coast of Scotland. European Journal of Archaeology 5. Pp. I47-I89.

Shennan, S. 2002. Genes, Memes and Human History: Darwinian Archaeology and Cultural Evolution. London: Thames and Hudson.

Siebers, T. 200r. Disability in Theory: From Social Constructionism to the New Realism of the Body, American Literary History. Oxford: Oxford University Press. Pp. 737-754.

Skoglund, P., Storå, J., Götherström, A. \& Jakobsson, M. 20I3. Accurate sex identification of ancient human remains using DNA shotgun sequencing. Journal of Archaeological Science 40. Pp. 4477-4482. 
Sofaer, J. R. 2006. The Body as Material Culture: A Theoretical Osteoarchaeology. Cambridge: Cambridge University Press.

Sørensen, M. L. S. I995. Reading Dress. The Construction of Social Categories and Identities in Bronze Age Europe. Journal of European Archaeology 5. Pp. 93-I I 4.

Sørensen, T. F. 20I3. We Have Never Been Latourian: Archaeological Ethics and the Posthuman Condition. Norwegian Archaeological Review. Vol. 46. No. I. Pp. I-I8.

Webmoor, T. 2007. What about "one more turn after the social" in archaeological reasoning? Taking things seriously. World Archaeology 39(4). Pp. 546-562.

Webmoor, T. \& Witmore, C. L. 2008. Things are us! A commentary on human/things relations under the banner of a "social archaeology". Norwegian Archaeological Review 4I (I). Pp. I-I8.

Welinder, S. 2003. DNA, etnicitet, folk och folkvandringar. Göteborg: Bricoleur Press.

Åsberg, C. 2005. Genetiska föreställningar: Mellan genus och gener i populär/vetenskapens visuella kulturer. Linköping: Linköpings Universitet. 